\title{
BIRD MIGRATION STUDY-SITE SIEMIANÓWKA (E POLAND) IN 2002-2003
}

\author{
Michał Polakowski, Monika Broniszewska, Alicja Krasnodębska, \\ Tomasz Tumiel and Anna Wnorowska
}

Polakowski M., Broniszewska M., Krasnodębska A., Tumiel T., Wnorowska A. 2004. Bird migration study-site Siemianówka (E Poland) in 2002-2003. Ring 26, 2: 99-106.

M. Polakowski, A. Krasnodębska, A. Wnorowska, Sekcja Ornitologiczna Koła Naukowego Biologów, Instytut Biologii, Uniwersytet w Białymstoku, Świerkowa 20B, PL-15-950 Białystok, Poland, E-mail: knb@uwb.edu.pl, akcja_siemianowka@wp.pl; M. Broniszewska, Pałecznica 152, PL-21-100 Lubartów, Poland; Tomasz Tumiel, Towarowa 2a/48, PL-15-007 Białystok, Poland

Publication appointed to the SE European Bird Migration Network papers

In the years 2002-2003 there was conducted a fieldwork for catching and ringing birds at the water reservoir Siemianówka $\left(52^{\circ} 55^{\prime} \mathrm{N}, 23^{\circ} 50^{\prime} \mathrm{E}\right)$ located in eastern part of Poland close to the country border with Belarus (Fig. 1). The reservoir is located on the River Narew, in its upper part, situated at the border between Białostocka and Bielska highlands (Kondracki 1998). The bird catching area was situated within willows (Salix sp.), reedbed, meadow and an around 40-years old pinestand (Pinus sylvestris) (Plate 1).

The main aim of the study was the collecting of data on bird migration in an inland locality situated far from any guiding lines that is usually a case in many other ringing sites.

The birds were caught from 4 August to 12 October 2002, and in periods: 17-25 April, 7 July - 4 November 2003, using differentiated number of mist-nets (Table 1) and funnel traps of Ottenby type (Meissner 1998). Nets controls were performed from dusk to dawn every hour and additionally once in an evening darkness. Bigmesh nets for owls and funnel traps for waders were controlled during a night every two hours. In bad weather conditions nets were controlled more frequently to avoid bird losses. Because of fluctuating water level in autumn 2003 some nets localities were changed. In addition to standard work with small-mesh nets that was rather stable over the season some short-term pilot catches of waders were done on eastern side of the reservoir at a mudy area near the shore and on a shallow water body near the camp locality (20-21 August 2002, 21 April 2003 and 18-20 August 2003). 


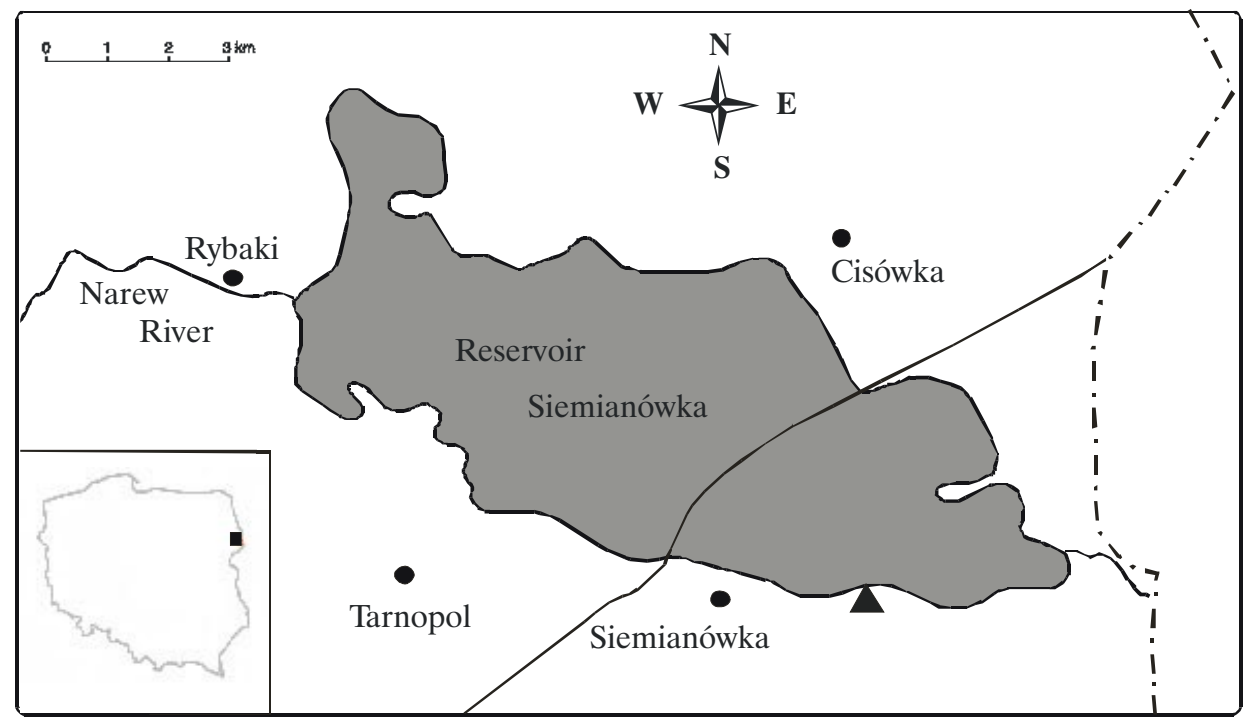

Fig. 1. Localisation of the ringing site Siemianówka. The camp location is pointed by a triangle.

Table 1

Numbers and parameters of nets/traps used in different years

\begin{tabular}{|l|c|c|c|}
\hline \multirow{2}{*}{ Mesh size / thread of nets } & \multirow{2}{*}{2002} & \multicolumn{2}{|c|}{2003} \\
\cline { 2 - 4 } & 4 Aug. - 12 Oct. & 17-25 Apr. & 7 Jul. - 4 Nov. \\
\hline $16 \mathrm{~mm}-235 / 2 \mathrm{dtex}$ & $35^{*}$ & $23^{*}$ & 45 \\
$19 \mathrm{~mm}-70 \mathrm{dtex}$ & 1 & 1 & 1 \\
$25 \mathrm{~mm}-235 / 2 \mathrm{dtex}$ & 3 & 0 & 1 \\
$40 \mathrm{~mm}-235 / 2 \mathrm{dtex}$ & 5 & 5 & 12 \\
$80 \mathrm{~mm}-235 / 2 \mathrm{dtex}$ & 0 & 0 & 2 \\
\hline Total nets & $46^{*}$ & $29^{*}$ & 61 \\
\hline Total funnel traps & 2 & 0 & $3^{*}$ \\
\hline
\end{tabular}

* average number of nets/traps

During work at the study site in years 2002-2003 there were ringed 8412 birds of 106 species (Table 2). Apart from ringing the birds were sexed and aged (if possible), measured (according to Busse 1983, 2000 and Svensson 1992) and checked for the fatness (fat-scores after Busse 2000). Many of them were tested for orientation using Busse's flat orientation cage (Busse 1995). It seems that results of these tests could be especially interesting as in Siemianówka there is no guiding lines that potentially could disturb orientation of migrants.

Looking at the general results of work special attention should be paid to species richness of the birds caught in Siemianówka - one of the highest noted in Poland (cf. Busse et al. 1985, 1989, 1993, Keller et al. 1997, Jędra and Ziaja 2000, Dylon et al. 2003). This suggests the species richness of the Northern Podlasie re- 
gion and confirms findings of authors writing mainly about breeding avifauna of the area (Dyrcz et al. 1984, Tomiałojć et al. 1984, Lewartowski and Piotrowska 1987, Gromadzki et al. 1994, Polakowski and Juniewicz 1998). Apart from the general causes of the avifauna abundance the high numbers of birds caught result from the location of the study site in the ecotone biotopes, which are usually frequently visited by different species of migrants.

Table 2

Birds ringed / retrapped and controlled (controls in brackets) in years 2002-2003

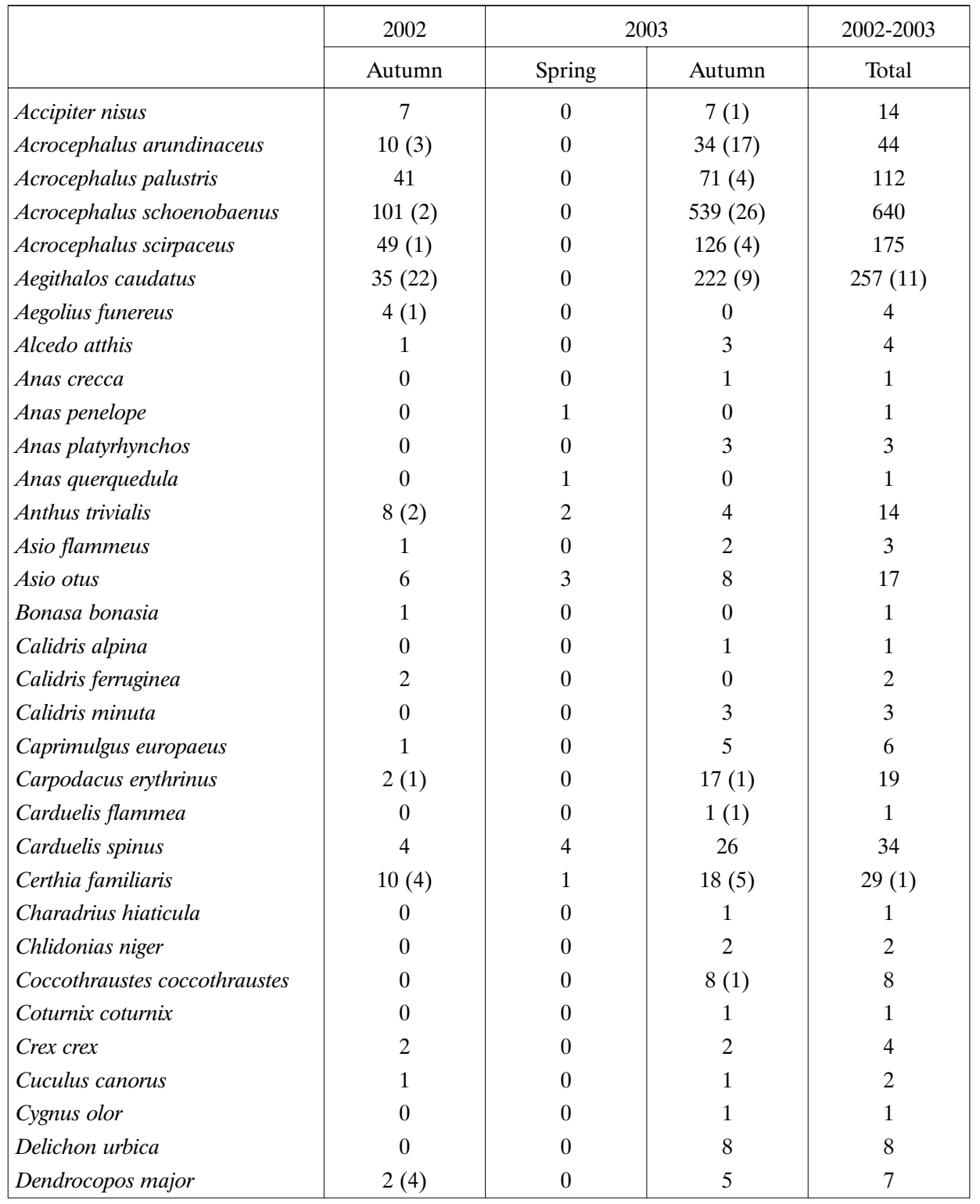




\begin{tabular}{|c|c|c|c|c|}
\hline & \multirow{2}{*}{$\frac{2002}{\text { Autumn }}$} & \multicolumn{2}{|c|}{2003} & \multirow{2}{*}{$\frac{2002-2003}{\text { Total }}$} \\
\hline & & Spring & Autumn & \\
\hline Dendrocopos medius & $1(1)$ & 0 & 0 & 1 \\
\hline Dendrocopos minor & $2(1)$ & 0 & $5(2)$ & 7 \\
\hline Dryocopos martius & 0 & 0 & 1 & 1 \\
\hline Egretta alba & 0 & 0 & 1 & 1 \\
\hline Emberiza citrinella & 13 & 3 & $7(4)$ & 23 \\
\hline Emberiza schoeniclus & 16 & 1 & $92(3)$ & 109 \\
\hline Erithacus rubecula & $731(142)$ & $165(13)$ & $551(69)$ & $1447(1)$ \\
\hline Ficedula albicollis & 0 & 0 & 4 & 4 \\
\hline Ficedula hypoleuca & 15 & 2 & 64 & 81 \\
\hline Ficedula parva & 4 & 0 & 6 & 10 \\
\hline Fringilla coelebs & 44 & $29(1)$ & 44 & $117(1)$ \\
\hline Gallinago gallinago & 2 & 0 & $16(2)$ & 18 \\
\hline Garrulus glandarius & 8 & 0 & 4 & 12 \\
\hline Glaucidium passerinum & 2 & 0 & 0 & 2 \\
\hline Hippolais icterina & $12(1)$ & 0 & 10 & 22 \\
\hline Hirundo rustica & 11 & 0 & 26 & 37 \\
\hline Jynx torquilla & 0 & 0 & 6 & 6 \\
\hline Lanius collurio & 0 & 0 & 14 & 14 \\
\hline Larus ridibundus & 0 & 0 & 1 & 1 \\
\hline Locustella fluviatilis & 6 & 0 & $6(1)$ & 12 \\
\hline Locustella luscinioides & 7 & 0 & 29 & 36 \\
\hline Locustella naevia & 6 & 0 & 4 & 10 \\
\hline Luscinia luscinia & 2 & 0 & $14(5)$ & 16 \\
\hline Luscinia svecica & 4 & 0 & $31(12)$ & 35 \\
\hline Lymnocryptes minimus & 0 & 0 & 3 & 3 \\
\hline Motacilla alba & 2 & 0 & $44(1)$ & 46 \\
\hline Motacilla citreola & 1 & 0 & 10 & 11 \\
\hline Motacilla flava & 0 & 0 & 119 & 119 \\
\hline Musicapa striata & $9(1)$ & 0 & 9 & 18 \\
\hline Nucifraga caryocatactes & 0 & 0 & 1 & 1 \\
\hline Oriolus oriolus & 0 & 0 & 3 & 3 \\
\hline Parus ater & $25(1)$ & 3 & $30(3)$ & 58 \\
\hline Parus caeruleus & $239(36)$ & 2 & $320(53)$ & $561(7)$ \\
\hline Parus cristatus & $5(3)$ & 1 & $8(7)$ & $14(3)$ \\
\hline Parus major & $311(57)$ & 0 & $352(59)$ & $663(2)$ \\
\hline Parus montanus & $39(29)$ & $1(1)$ & $45(11)$ & $85(10)$ \\
\hline Parus palustris & $22(11)$ & 0 & $8(1)$ & 30 \\
\hline Perdix perdix & 0 & 2 & 0 & 2 \\
\hline Philomachus pugnax & 3 & 0 & 5 & 8 \\
\hline Phoenicurus ochruros & 1 & 0 & 2 & 3 \\
\hline Philomachus phoenicurus & $7(2)$ & 0 & 3 & 10 \\
\hline Phylloscopus collybita & $574(34)$ & $58(2)$ & $283(22)$ & $915(4)$ \\
\hline Phylloscopus sibilatrix & 12 & 0 & 18 & 30 \\
\hline
\end{tabular}




\begin{tabular}{|c|c|c|c|c|}
\hline & \multirow{2}{*}{$\begin{array}{c}2002 \\
\text { Autumn }\end{array}$} & \multicolumn{2}{|c|}{2003} & \multirow{2}{*}{$\begin{array}{c}\text { 2002-2003 } \\
\text { Total } \\
\end{array}$} \\
\hline & & Spring & Autumn & \\
\hline Phylloscopus trochilus & 136 & 10 & 114 & 260 \\
\hline Picus canus & $1(1)$ & 0 & 0 & 1 \\
\hline Porzana parva & 0 & 0 & 1 & 1 \\
\hline Porzana porzana & 0 & 0 & 3 & 3 \\
\hline Prunella modularis & $71(3)$ & 6 & $33(2)$ & 110 \\
\hline Pyrrhula pyrrhula & $40(26)$ & 1 & $24(2)$ & 65 \\
\hline Regulus regulus & 35 & 0 & $72(7)$ & 107 \\
\hline Remiz pendulinus & 4 & 0 & 1 & 5 \\
\hline Riparia riparia & 0 & 0 & 4 & 4 \\
\hline Saxicola rubetra & $16(1)$ & 0 & $56(3)$ & $72(1)$ \\
\hline Scolopax rusticola & 5 & 0 & 3 & 8 \\
\hline Sitta europaea & 2 & 0 & 0 & 2 \\
\hline Strix aluco & 2 & 0 & 0 & 2 \\
\hline Sylvia atricapilla & $390(96)$ & 1 & $250(51)$ & $641(1)$ \\
\hline Sylvia borin & $158(32)$ & 0 & $116(20)$ & 274 \\
\hline Sylvia communis & $60(12)$ & 0 & 99 (17) & 159 \\
\hline Sylvia curruca & $60(7)$ & 0 & $53(11)$ & 113 \\
\hline Sylvia nisoria & 2 & 0 & $10(2)$ & 12 \\
\hline Tachybaptus ruficollis & 0 & 0 & 1 & 1 \\
\hline Tringa erythropus & 0 & 0 & 3 & 3 \\
\hline Tringa glareola & 7 & 0 & 41 & 48 \\
\hline Tringa nebularia & 0 & 0 & 3 & 3 \\
\hline Tringa ochropus & 0 & 0 & 2 & 2 \\
\hline Tringa totanus & 0 & 0 & 1 & 1 \\
\hline Troglodytes troglodytes & $20(3)$ & 0 & $24(3)$ & 44 \\
\hline Turdus iliacus & 0 & 3 & 0 & 3 \\
\hline Turdus merula & $170(50)$ & 2 & $90(6)$ & $262(3)$ \\
\hline Turdus philomelos & $94(5)$ & 15 & $63(3)$ & 172 \\
\hline Turdus pilaris & 6 & 0 & 5 & 11 \\
\hline Turdus viscivorus & 1 & 0 & 0 & 1 \\
\hline Total individuals & 3704 & 317 & 4391 & 8412 \\
\hline Number of species & 73 & 24 & 93 & 106 \\
\hline
\end{tabular}

The most commonly ringed five species were: the Robin Erithacus rubecula 17.2\%, the Chiffchaff Phylloscopus collybita $-10.9 \%$, the Great Tit Parus major $7.9 \%$, the Blackcap Sylvia atricapilla $-7.6 \%$ and the Sedge Warbler Acrocephalus schoenobaenus $-7.6 \%$. Altogether these dominants reached $45.7 \%$ of all birds ringed in 2002, but only $24.8 \%$ in 2003. Similar species composition was noted at the Kaliszany ringing site in the Middle Vistula Valley in 2000-2001 (Dylon et al. 2003), but there the share of dominants was higher $-58.8 \%$, and at the Operation Carpatica ringing site in southern, mountainous part of Poland in 1998-1999 (Jędra and Ziaja 2000). At the latter site the share of Chiffchafs was particularly high, 
while this of Robins was similar to our results at Siemianówka. Results of work of the Operation Vistula, situated by the River Vistula, showed dominance of Chiffchaffs and Robins, while Blackcaps and Dunnocks Prunella modularis were a little bit less numerous. Some of mentioned differences in numbers of Chiffchaffs could be caused by different kind of nets used at Siemianówka (with rather thick thread) in contrast to thin-thread nets at two other sites.

Clearly different species composition was noted at the Operation Baltic stations situated at the sea coast. In 2003 Robins, Blue Tits Parus caeruleus and Great Tits dominated there (Operation Baltic unpubl.) and total numbers per station were much bigger than at the Siemianówka site. Such situation is generally observed when comparing coastal and inland ringing stations (Busse et al. 1985, 1989, 1993, Keller et al. 1997, Jędra and Ziaja 2000, Dylon et al. 2003, Polakowski et al. in press). At the coastal stations diurnal migrants guided by the coast are easily caught during active migration along narrow stripes of forest covering coastal dunes.

In 2003 at Siemianówka we caught many reedbed birds (20.4\% of all birds caught versus $6 \%$ in 2002). The most common were the Sedge Warbler - 539 indiv., and the Reed Warbler Acrocephalus scirpaceus - 126 indiv. These differences could be caused by both the different number of migrants and the local situation as to water level in the reservoir (in 2003 the level of water was much higher than in 2002). At the "reedbed site" - Lake Drużno (N Poland) in years 1999-2001 the most common were Reed Warblers and Sedge Warblers while the Marsh Warbler Acrocephalus palustris was less numerous (Jakubas et al. 2002).

During the work at Siemianówka some Wood Sandpipers Tringa glareola were ringed and colour-marked according to "Tringa glareola 2000" project (Remisiewicz 2002). In 2002 seven birds were ringed with colour rings and in $2003-35$ indiv.

Several birds ringed at Siemianówka were controlled. Altogether 1056 catches were short-term controls during the same season (retraps) and 46 birds were caught at the site later on (Table 2). These numbers are rather high in relation to other locations (e.g. Busse et al. 1993). Eight birds gave long-distance recoveries: two from Italy - a Wood Sandpiper and a Chaffinch Fringilla coelebs, two from France a Woodcock Scolopax rusticola and a Reed Warbler, two from Lithuania - Long-

Table 3

Late occurences of some species

\begin{tabular}{|l|c|c|}
\hline & Sex/age & Last observation date \\
\hline Acrocephalus arundinaceus & imm. & 30 Sep. 2002 \\
Acrocephalus palustris & f.g. & 6 Oct. 2002 \\
Ficedula parva & imm. & 8 Oct. 2003 \\
Hippolais icterina & $i m m$. & 6 Sep. 2003 \\
Locustella fluviatilis & $i \mathrm{imm}$. & 31 Aug. 2002 \\
Locustella fluviatilis & $i \mathrm{~mm}$. & 15 Sep. 2003 \\
Locustella luscinioides & $i \mathrm{~mm}$. & 22 Sep. 2003 \\
Phylloscopus trochilus & $\mathbf{i m m}$. & 11 Oct. 2002 \\
Phoenicurus ochruros & imm. & 26 Oct. 2003 \\
\hline
\end{tabular}


tailed Tits Aegithalos caudatus, one from Hungary - a Sedge Warbler, and one from the Czech Republic - a Bluethroat Luscinia svecica.

The work gave a number of faunistically interesting findings as e.g. the Hazel Grouse Tetrastes bonasia, the Little Crake Porzana parva, the Great Egret Egretta alba and ten Citrine Wagtails Motacilla citreola (Polakowski et al. 2004). In comparison to the known phenology of birds in Poland (Tomiałojć and Stawarczyk 2003) there were noted unusually late records of some species (Table 3).

\section{ACKNOWLEDGEMENTS}

The work was carried out under auspices of the SEEN (SE European Bird Migration Network).

We acknowledge the work of ringers that collected the data (R. Bargiel, Ł. Borek, T. Cofta, M. Keller, P. Marczakiewicz, L. Meina, J.K. Nowakowski, D. Piec, M. Polak, M. Polakowski, M. Sidelnik, M. Ściborski, J.R.E. Taylor, T. Tumiel, P. Wencel) as well as the help of around 150 people from different parts of Poland (and one person from France as well).

We would like to thank all who helped us in organisation of the work: Prof. Dr Alina Myrcha, Dr W. Chętnicki, Dr J.R.E. Taylor, Prof. Dr P. Busse, G. Grzywaczewski and M. Skoracki. We are indebted to Dr W. Chętnicki, K. Sidoruk, $Ł$. Mazurek and $Ł$. Meina for their help and criticism in preparation of this publication.

We thank also to the Regional Fund for Water Resources and Protection of the Environment in Białystok and to the Students Parliament of the Białystok University for a subsidy, which allowed to work in the field. The Regional Bureau of Melioration and Water Management allowed us to stay at their property.

Finally we warmly thank to K. and A. Polakowski and W. and J. Tumiel as well as to our neighbours in the field - H. and M. Kiczkajto for all support and the atmosphere, which allowed us to work so hard.

\section{REFERENCES}

Busse P. 1983. Biometrical standards in the Operation Baltic work. Ring 116: 125-138.

Busse P. 1995. New technique of a field study of directional preferences of night passerine migrants. Ring 17 , 1-2: 97-116.

Busse P. 2000. Bird Station Manual. Gdańsk Univ., Gdańsk.

Busse P., Cofta T., Petryna A. 1985. Operation Baltic 1984. Polish Section. Activity report. Not. Orn. 26: 73-78.

Busse P., Cofta T., Petryna A. 1989. Operation Baltic 1988. Polish Section. Activity report. Not. Orn. 30: 111-114.

Busse P., Cofta T., Petryna A. 1993. Operation Baltic 1990-1992. Polish Section. Activity report. Not. Orn. 34: 183-193.

Dylon K., Rudolf R., Szewczyk P., Grzywaczewski G., Deptuś P., Krogulec J. 2003. [The autumn birds migration through the Central Vistula Valley in the years 2000-2001]. Materiały VII Ogólnopolskiego 
Przeglądu Działalności Studenckich Kół Naukowych Przyrodników, Białystok 21-23 listopada 2003.Białystok Univ., Białystok. (In Polish).

Dyrcz A., Okulewicz J., Witkowski J., Jesionowski J., Nawrocki P., Winiecki A. 1984. Birds of fens in Biebrza Marshes. Faunistic approach. Acta orn. 20: 1-108.

Gromadzki M., Dyrcz A., Głowaciński Z., Wieloch M. 1994. Ostoje ptaków w Polsce. Ogólnopolskie Towarzystwo Ochrony Ptaków, Gdańsk (in Polish).

Jędra M., Ziaja W. 2000. Sprawozdanie z prac Akcji Carpatica w latach 1998-1999. Not. Orn. 41: 179-181.

Jakubas D., Michno B., Nitecki C., Ulatowska J. 2002. Raport on passerines ringed in the "Lake Drużno" reserve in 1999-2001. Ring 24: 77-82.

Keller M., Rowiński P., Nowakowski J.K., Maniakowski M. 1997. [Vistula Operation - students camp of bird ringing on the Middle Course of Vistula in 1983-1996.] Kulon 2: 232-243. (In Polish).

Kondracki J. 1998. Geografia regionalna Polski. PWN, Warszawa (in Polish).

Lewartowski Z., Piotrowska M. 1987. Birds breeding in the valley of the Narew river, Poland. Acta orn. 23: $215-272$.

Meissner W. 1998. Some notes on using walk-in traps. Wader Study Group Bull. 86: 33-35.

Polakowski M., Juniewicz M. 1998. Autumn migration of waders at the sewage treatment plant in Fasty near Biatystok (Eastern Poland). Ring 20: 59-67.

Polakowski M., Tumiel T., Wnorowska A., Broniszewska M. 2004. [Rare birds caught and ringed during Operation Siemianówka in 2002-2003.] Materiały XXXIII Międzynarodowych Seminariów Kół Naukowych. Warmia and Masuria Univ., Olsztyn: 98-100. (In Polish).

Polakowski M., Krasnodębska A., Tumiel T., Wnorowska A. in press. [Results of ringing birds near Siemianówka Reservoir in 2002.] Drozdowskie Zeszyty Przyrodnicze, Drozdowo. (In Polish).

Remisiewicz M. 2002. The present state and perspectives of the project "Tringa glareola 2000". Ring 24, 1: $35-40$.

Svensson L. 1992. Identification Guide to European Passerines. Stockholm, Sweden.

Tomiałojć L., Wesołowski T., Walenkiewicz W. 1984. Breeding bird community of a primaeval temperate forest (Białowieża National Park, Poland). Acta orn. 20: 241-310.

Tomiałojć L., Stawarczyk T. 2003. The avifauna of Poland. Distribution, numbers and trends. PTPP "pro Natura", Wrocław. 